\title{
ISOLATION OF MOTILE AEROMONAS SPECIES FROM CHICKEN FAECES
}

\section{MEHMET AKAN*}

\section{K.SERDAR DIKKER"}

\section{Tavuk Dışkılarından Hareketli Aeromonas Türlerinin İzolasyonu}

Özet: Hareketli Aeromonas türleri, 21 kümesten alınan 254 ishalli ve 254 normal dişk örneğinde direkt ve zenginleştirme metodlarl ile araştırlda. Direkt metotta 15 (\%2.9), zenginleştirme metodunda ise 89 (\%17.5) örnekte hareketli Aeromonas türleri saptand. Hareketli Aeromonaslar, incelenen 254 ishalli örneğin 48'inden (\%18.8) ve 254 normal dişkl örneğinin 4l'inden (\%16.1) izole edildi. Bu izolatlarin 53 'ü (\%59.6) A hydrophila, 14'ii (\%15.7) A.sobria ve 22 'si (\%24.7) A.caviae olarak identifiye edildi. A.hydrophila hem ishalli hem de normal orneklerde daha yüksek oranda izole edildi.

Anahtar kelimeler: Hareketli Aeromonas türleri. izolasyon, tavuk, $d i s ̧ k$

Summary: Motile Aeromonas species from 21 different poultry flocks were investigated in 254 diarrhoeic and 254 apparently normal faeces samples by direct plating and enrichment methods. Aeromonas spp. were detected in 15 $(2.9 \%)$ samples by the direct plating method and found in $89(17.5 \%)$ samples by enrichment method. Motile aeromonads were isolated from 48 (18.8\%) of 254 diarrhoeic faeces and 41 (16.1\%) of 254 apparently normal faecal samples, tested. Among these isolates, $53(59.6 \%), 14(15.7 \%)$ and 22 (24.7\%) were identified as A.hydrophila. Asobria and A.caviae. respectively. A. hydrophila was more prevalent either in diarrhoeic or normal chickens.

Key words: Motile Aeromonas species, isolation, chicken, faeces

\section{Introduction}

Bacteria of the motile Aeromonas group (A.hydrophila, A.sobria, A.caviac) occur widely in fresh, estuarine waters, chlorinated drinking water, and bottled water $(12,23)$ and are recognized as pathogens of fish, amphibians and reptiles $(1,14)$. Motile Aeromonas species have become increasingly implicated as the causative agents of diarrhoea, wound infections and septicemia in humans $(7,8,10,22)$. They have also been recovered from the faecal material of pigs and cattle, and found to be common contaminants in foods of animal origin $(2,6,9,11,17)$. The studies related with the motile aeromonads of poultry are so limited. Isolation of motile aeromonads from the faeces of turkey, pet and aviary birds has been reported in a few occasion $(16,21,24)$.dditionally, pathologic conditions in birds due to these organisms have been defined only in a few reports $(4,18)$. Recently, A.hydrophila has been isolated from an outbreak of diarrhoea in a flock and this agent has been implicated as a cause of infectious enteritis in poultry (3).

The aim of this study was to determine the role of motile Aeormonas spp. in naturally occuring diarrhoeal diseases of chickens.

\section{Material and Methods}

Animals: Six week old chickens showing signs of watery, mucoid and bloody diarrhoca were determined in 21 flocks. Duplicate rectal samples were collected from 254 diarrhoeic chickens. As non-diarrhoeic controls, duplicate rectal samples were also obtained from 254 healthy chickens of same 
flocks in equal numbers. Healthy chickens were observed along three days for a subsequent diarrhoeal condition. Chickens had not been received antimicrobial agents as feed additives or thcurepatics along 2 weeks prior to sampling.

Isolation: All rectal contents were taken into sterile containers and examined within two hours of sampling. For the isolation of motile aeromonads, direct and enrichment methods were used. In direct plating, faecal samples were strcaked on blood-ampicillin agar (BAA) containing $5 \%$ sheep blood and $10 \mathrm{mg} / \mathrm{l}$ ampicillin, using sterile swabs. In enrichment procedure, Ig of faecal sample was inoculated into $10 \mathrm{ml}$ of alkaline peptone water (APW, $\mathrm{pH} 8.4$ ) and incubated at $28^{\circ} \mathrm{C}$ for $24 \mathrm{~h}$. APW was further diluted $(1: 10)$ with phosphate buffered saline and samples were plated on BAA with an inoculating loop. All plates werc incubated at $28{ }^{\circ} \mathrm{C}$ for $24 \mathrm{~h}$.

Identification: Hemolytic colonics from BAA were examined for motility and Gram's reaction and were transferred to nutrient agar slants. After an overnight incubation at $28{ }^{\circ} \mathrm{C}$, a few drops of a $1 \%$ solution of $\mathrm{N}, \mathrm{N}$-dimethyl-pphenylenediamine monohydro-chloride were added to the growth to determine the oxidase activity. All Gram-negative, oxidase-positive and motile organisms were screened with the following tests: oxidation/fermentation of glucose $(\mathrm{O} / \mathrm{F})$, sensitivity to 2,4-diamino-6,7diisopropyl-pteridine (vibriostatic agent, $\mathrm{O} / 129$ ), fermentation of mannitol and salicin, utilisation of arabinose, gas production from glucose, $\mathrm{H}_{2} \mathrm{~S}$ production from cysteine hydrochloride and acsculin hydrolysis. Aeromonas spp. were differentiated according to criteria described by Popoff (19).

Statistical analysis: The significance of difference between groups was tested by chisquare analysis.

\section{Results and Discussion}

Motile aeromonads were isolated from $48(18.8 \%)$ of 254 diarrhocic and $41(16.1 \%)$ of 254 apparently normal chickens (Table.1). Difference between carriage rates of two groups was not significant $(p>0.05)$. Motile aeromonads wcre found in all 21 flocks investigated. The isolation rate ranged from 12.3 to $24.6 \%$ from flock to flock. Additionally: Aeromonas carriage rate was not significant in any of the flocks $(p>0,05)$. Any specific clinical sign was not detected in Aeromonas harbouring animals; all threc types of diarrhoea (watery, mucoid and bloody) were present. The findings of this study suggested that motile aeromonads were not the cause of diarrhoea of chickens investigated. This finding is in contrast to that reported by Efuntoye (3) who isolated A.hydrophila from $56.0 \%$ of diarrhoeic and $15.4 \%$ of healthy chicken faeces and suggested that specifically A.hydrophila was closely assocciated with the outbreaks of diarrhoea in the poultry. Since the findings of Efuntoye (3) have been obtained from only one flock and an experimental infection has not been performed, the suggestion of researcher is not convincing.

Table 1 . Motile Aeromonas species in diarrheic and normal faeces. Tablo 1. Normal ve ishalli dıskilarda hareketli Aeromonas türleri.

\begin{tabular}{|c|c|c|c|c|}
\hline $\begin{array}{c}\text { Type of } \\
\text { samples }\end{array}$ & $\begin{array}{c}\text { No. of } \\
\text { isolates } \\
(\%)\end{array}$ & $\frac{\text { A.livdrophila }}{(\%)}$ & $\frac{\text { A.sobria }}{(\%)}$ & $\frac{\text { A.caviace }}{(\%)}$ \\
\hline diarrhoeic & $48(18.8)$ & $27(56.3)$ & $9(18.7)$ & $12(25.0)$ \\
\hline normal & $41(16.1)$ & $26(63.4)$ & $5(12.2)$ & $10(24.4)$ \\
\hline total & $89(17.5)$ & $53(59.6)$ & $14(15.7)$ & $22(24.7)$ \\
\hline
\end{tabular}

On the other hand, when the results of present study was evaluated by means of a single species, A.hydrophila, the difference between groups was not significant. Some workers $(9,24)$ have reported the low incidence of motile aeromonads in poultry faeces. Jindal et al.(9) reported that Acromonas spp. were isolated from 2 of 10 poultry faeces. Stern et al.(24) found Acromonas spp. from 3 of 21 turkey faeces. These workers, however have not indicated the clinical condition of animals. A further comparison with other studies was not possible as a detailed study on the isolation of motile acromonads species in normal and diarrhoeic faeces has not been done before

When the isolation methods were compared, a significant difference was found $(\mathrm{p}<0.01)$. Motile aeromonads were detected in $15(2.9 \%)$ of 508 samples by direct plating method and $89(17.5 \%)$ by enrichment method (Table.2). All direct-plating samples were also positive in enrichment method. These results have showed that enrichment step is necessary for the primary isolation of motile aeromonads from faeces. The similar results reported in some studies $(6,13)$. Gray ve Stickler $(6)$ reported that an enrichment technique with APW from feaces increased the total number of isolates by $77.1 \%$ for isolation of A.hydrophila. Majeed et al.(13) who detected in motile acromonads $11 \%$ of faecal samples by enrichment methods were unable to isolate any motile aeromonads by direct plating methods. 
Talle 2. Methods of isolation: Comparison in numbers (\%) of positive cultures.

Tablo 2. Izolasyon metotları: Pozitif kültürlerin (\%) karşılaştrılmass.

\begin{tabular}{|c|c|c|}
\hline $\begin{array}{c}\text { Vo. of samples } \\
\text { examined }\end{array}$ & $\begin{array}{c}\text { positive samples } \\
\text { on direct plating } \\
\text { (isolation \%) }\end{array}$ & $\begin{array}{c}\text { positive samples } \\
\text { after enrichnent } \\
\text { (isolation \%) }\end{array}$ \\
\hline 508 & $15(2.9)$ & $89(17.5)$ \\
\hline
\end{tabular}

All of the 89 strains selected for identification were found to be motile Aeromonas spp. These strains comprised 48 from diarrhoeic and 41 from normal faecal samples. All strains werc motilc and oxidasepositive. Based on their reactions in aesculin hydrolysis, L-arabinose utilisation, fermentation of salisin, production of gas from glucose and $\mathrm{H}_{2} \mathrm{~S}$ from cysteine, the strains were identified as A.hydrophila, A.sobria and A caviae (Table 3). Of these 89 isolates, $53(59.6 \%)$ werc identified as A.hydrophila, $14(15.7 \%)$ as A.sobria and 22 $(24.7 \%)$ as A.caviac. It was clearly demonstrated that A hydrophila predominated in both diarrhoeic and normal chicken faeces. It has also been generally accepted by other researchers that A.hydrophila is the most common motile Acromonas species in either environmental samples or animal hosts $(4,5,6,15,20)$.

Table 3. Differential characteristics of motile Aeromonas species Tablo 3. Hareketli Aeromonas türicrinin ayırıcı özellikleri.

\begin{tabular}{|c|c|c|c|}
\hline Characteristics & A.hydrophila & A.sobria & A.cavine \\
\hline Catalase & + & + & 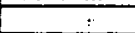 \\
\hline Oxidasc & + & + & + \\
\hline Motility & + & + & + \\
\hline Rcsistant to 0/129* & + & + & 7 \\
\hline Oxidation-fermentation & Fermentative & crmentative & Crmentative \\
\hline Fermentation of & + & $r$ & + \\
\hline Acsculin hydrolysis & + & - & $=$ \\
\hline Arabinose utilization & + & - & + \\
\hline Fermentation of salicin & 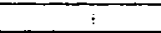 & - & + \\
\hline Gas fiom glucose & $r$ & + & - \\
\hline $\mathrm{H}_{2} \mathrm{~S}_{\text {from }} \mathrm{cysteine}$ & + & $!$ & - \\
\hline
\end{tabular}

*2-4 diamino 6-7 diisoprophyl pteridine

\section{References}

1. Austin, B., Allen - Austin, D.(1985) A reviewbacterialpathogens of fish. J.Appl. Bacteriol., 58, 483-506.

2. Bucnanan, R.'T., Palumbo, S.A.(1985) Aeromonas hydrophila and Aeromonas sobria as a potential food poising species: A review. J. Food Safety, 7, 15-29.

3. Ffuntoye, M.O.(1995) Diarrhoea disease in livestock associated with Aeromonas hydrophila biotype 1. J.Gen.Appl.Microbiol., 41, 517 -521.

4. Garcia, M.E., Domenech, A., Dominguez, L., Kamiro, F., Femandez-Garayzbal, J.F.(1992) Aeromonas hydrophila confuctivitis in a pet parrot (Amozona versicolor). Avian IDis.. 36, $1110-1111$.
5. Gray, S.J.(1984) Aeromonas hydrophla in livestock: incidence, biochemical characteristics and antubiotics susceptubility: J. Hyg. 92, 365-375.

6. Gray, S.J., Stickler, D.J. (1989) Some observations on the faecal carriae of mesophillic Aeromonas species in cows and pig.s. Epidemiol. Infect., 103, 523-537.

7. Gray, S.J., Griffiths, A.(1990) Observation on Aeromonas species isolated from human faeces. J. Infect, 20, 267-268.

8. Janda, J.M., Brenden, R.(1987) Importance of Aeromonas sobria in Aeromonas bacteraemia. J. Infect.Dis., 155, 589. 591 .

9. Jundal, N., Garg, S.R., Kumar, A (1993) Comparison of Aeromonas spp. isolated from human. livestock and poultry faeces. Isr. J. Vet. Med., 48, 80-83

10. Joseph, S.W., Daily, O.P., Hunt, W.S., Scidler, R.J., Allen, D.A., Cohvell, R.R. (1979) Aeromonas primary wound infection of a diver in polluted water. J. Clin. Microbiol., 10. 46.49 .

11. Kirov, S.M., Anderson, M.I., Mc Meekin, T.A.(1990) A. note on Aeromonas spp. from chickens as possible foodborne pathogens. J. Appl. Bacteriol. 68, 327-334.

12. Lechevallicr, M.W., Evans, T.M., Seidler,R.J., Dailly, O.P., Merrell, B.R., Rollins, D.M., Joseph, S.W. (1988) Aeromonas sobria in chlorinated drinking water suplies. Micrub. Ficol. 8, 325-333.

13. Majeed, K.N., Egan, A.F., Mackae, I.C. (1989) Incidence of aeromonads in samples from an abottor proccessing lambs. J. Appl Bacteriol., 67, 597-604.

14. Marcus, L.C. (1971) Infectous diseases of reptiles. JAVMA. 159. 1629-1631

15. Mishra, S., Nair, G.B., Bhadra, R.K., Sukder, S.D., Pal, S.C. (1987) Comparison of selective media for primary isolation of Aeromonas species from human and anmal feces. I. Clin.Microbiol., 25, 2040-2043.

16. Needman, J.R., Mathewson, J.J., Hall, C.F., Grubles, L.C. (1979) $A$ sturvey of the aerobic bacteria in the droppings of captive birs of prey. Res. Vet. Sci., 27, 125-126.

17. Palumbo, S.A., Bencivengo, M.M., Corral, F.D., Williams, A.C., Buchaman, R.I.(1989) Characterization of the Aeromonas hydrophila group isolated from retail foods of animal orijin. J. Clin. Microbiol., 27, 854-859.

18. Panigrahy, B.J., Mathewson, J.J., Hall, C.F., Grumbles, l.C. (1981) Unusual disase conditions in pet and aviary birds. JAVMA, 178, 394-395.

19. Popoff, M.(1984) Aeromonas. 545-546. In: Krieg. M.R. IHolt, J.G.(Eds.): Bergey's Manual of Systematic Bacteriology. Vol.1, Williams and Wilkins. Baltimore/London.

20. Seidler, R.J., Allen, D.A., Lockman, H., Colwell, R.R., Joseph, S.W., Dailly, O.P. (1980) Jsolation. zmeration. and characterization of Aeromonas from polluled waters encountered in diving operations. Appl. Environ. Microbiol. 39. $1010-1018$.

21. Shane, S,M, Harrington, K.S., Montrose, M.S., Rocbuck, R.G. (1984) The occurrence of Aeromonas hydrophila in avian diagnosfic submissions. Avian Dis., 28, 804-808

22. Shread, P., Donovan, T.J., Lec, J.V. (1981) A survey of the incidence of Aeromonas in human faeces. SocGen. Microhiol. Quart. 8, 184. 